Keywords: $D W P F$, sludge, glycolic

Retention: Permanent

\title{
Glycolic Acid Physical Properties, Impurities, and Radiation Effects Assessment
}

\author{
B. R. Pickenheim \\ N. E. Bibler \\ D. P. Lambert \\ M. S. Hay
}

June 20, 2011

Savannah River National Laboratory Savannah River Nuclear Solutions Aiken, SC 29808

Prepared for the U.S. Department of Energy under contract number DE-AC09-08SR22470.

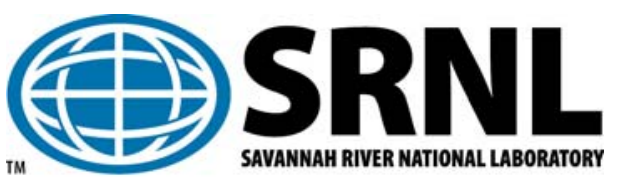


SRNL-STI-2010-00314

Revision 1

\section{DISCLAIMER}

This work was prepared under an agreement with and funded by the U.S. Government. Neither the U.S. Government or its employees, nor any of its contractors, subcontractors or their employees, makes any express or implied:

1. warranty or assumes any legal liability for the accuracy, completeness, or for the use or results of such use of any information, product, or process disclosed; or

2. representation that such use or results of such use would not infringe privately owned rights; or

3. endorsement or recommendation of any specifically identified commercial product, process, or service.

Any views and opinions of authors expressed in this work do not necessarily state or reflect those of the United States Government, or its contractors, or subcontractors.

\section{Printed in the United States of America \\ Prepared for \\ U.S. Department of Energy}




\section{REVIEWS AND APPROVALS}

\section{AUTHORS:}

TECHNICAL REVIEW:

APPROVAL:

C.C. Herman, Manager

Date

Process Technology Programs

Date

S.L. Marra, Manager

Environmental \& Chemical Process Technology Research Programs

J.E. Occhipinti, Manager

Date

Waste Solidification Engineering 


\section{EXECUTIVE SUMMARY}

The DWPF is pursuing alternative reductants/flowsheets to increase attainment to meet closure commitment dates. In fiscal year 2009, SRNL evaluated several options and recommended the further assessment of the nitric/formic/glycolic acid flowsheet. SRNL is currently performing testing with this flowsheet to support the DWPF down-select of alternate reductants. As part of the evaluation, SRNL was requested to determine the physical properties of formic and glycolic acid blends.

Blends of formic acid in glycolic acid were prepared and their physical properties tested. Increasing amounts of glycolic acid led to increases in blend density, viscosity and surface tension as compared to the $90 \mathrm{wt} \%$ formic acid that is currently used at DWPF. These increases are small, however, and are not expected to present any difficulties in terms of processing.

The effect of sulfur impurities in technical grade glycolic acid was studied for its impact on DWPF glass quality. While the glycolic acid specification allows for more sulfate than the current formic acid specification, the ultimate impact is expected to be on the order of $0.03 \mathrm{wt} \%$ sulfur in glass. Note that lower sulfur content glycolic acid could likely be procured at some increased cost if deemed necessary.

A paper study on the effects of radiation on glycolic acid was performed. The analysis indicates that substitution of glycolic acid for formic acid would not increase the radiolytic production rate of $\mathrm{H}_{2}$ and cause an adverse effect in the SRAT or SME process. It has been cited that glycolic acid solutions that are depleted of $\mathrm{O}_{2}$ when subjected to large radiation doses produced considerable quantities of a non-diffusive polymeric material. Considering a constant air purge is maintained in the SRAT and the solution is continuously mixed, oxygen depletion seems unlikely, however, if this polymer is formed in the SRAT solution, the rheology of the solution may be affected and pumping of the solution may be hindered. However, an irradiation test with a simulated SRAT product supernate containing glycolic acid in an oxygen depleted atmosphere found no evidence of polymerization. 


\section{TABLE OF CONTENTS}

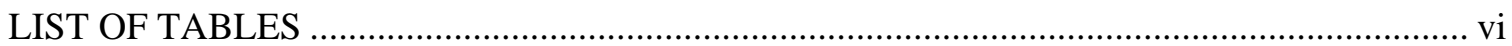

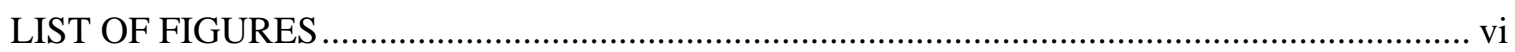

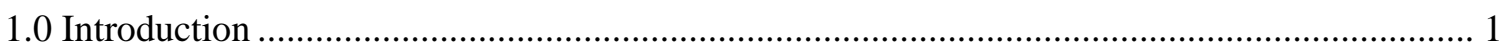

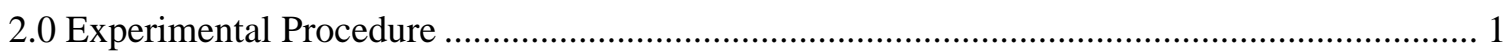

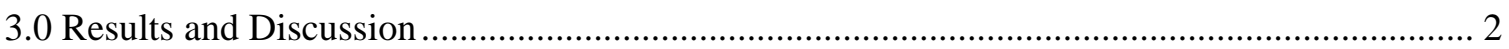

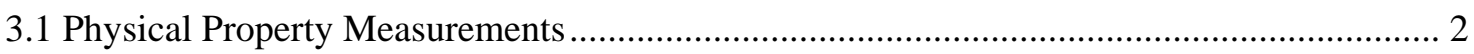

3.2 Glycolic Acid Impurity Evaluation................................................................................ 4

3.3 Radiation Effects on Glycolic-Formic Acid Blend............................................................. 5

3.4 Radiation Effects on Simulated SRAT Product Supernate................................................ 7

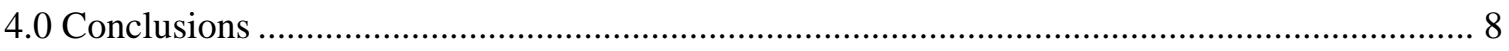

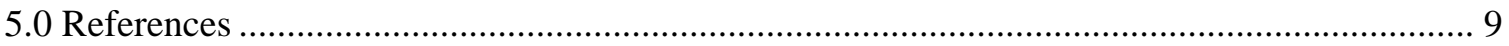




\section{LIST OF TABLES}

Table 2-1. Glycolic-Formic Acid Blend Preparation ................................................................ 1

Table 3-1. Physical Properties of Glycolic-Formic Acid Blends .............................................. 2

Table 3-2. Glycolic Acid Determination Using Density Measurement ..................................... 4

Table 3-3. Fractions of Radiolytic H Atoms Reacting with Formate, Nitrate and Nitrite in SB3 SRAT Solution.

Table 3-4. Reactivities of H Atoms in a SRAT Solution with 80:20 Molar Blend of

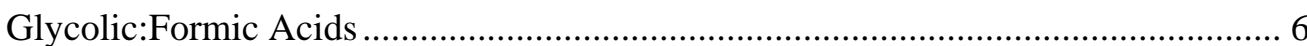

Table 3-5. Anion Analysis of the SRAT Product Supernate Samples ......................................... 7

\section{LIST OF FIGURES}

Figure 3-1. Effect of Formic Acid Concentration on Blend Viscosity ......................................... 3

Figure 3-2. Effect of Formic Acid Concentration on Blend Density ............................................ 3

Figure 3-3. GF-13 Post SRAT Supernate after Irradiation............................................................. 8 


\section{LIST OF ABBREVIATIONS}

ACTL

CPC

DWPF

PSAL

SRNL

SRAT

SME
Aiken County Technology Laboratory Chemical Process Cell

Defense Waste Processing Facility

Process Science Analytical Laboratory

Savannah River National Laboratory

Sludge Receipt and Adjustment Tank

Slurry Mix Evaporator 


\subsection{Introduction}

As part of the development of a glycolic-formic acid flowsheet for the Defense Waste Processing Facility (DWPF) Chemical Process Cell (CPC), Savannah River National Laboratory (SRNL) was requested to determine and assess the physical properties of the potential glycolic-formic acid blend to be implemented. ${ }^{1}$ Five blends of glycolic and formic acids at varying concentrations were made and tested for density, surface tension and viscosity. Additionally, the impact of glycolic acid impurities on DWPF glass quality was assessed and a paper study on the effects of radiation on glycolic acid was performed. This work was performed under the guidance of a Task Technical and Quality Assurance Plan. ${ }^{2}$

\subsection{Experimental Procedure}

Blends of formic acid in glycolic acid at 5, 10, 15, 20 and 25\% on a molar basis were prepared for this study. Note that formic acid is supplied as a $90 \mathrm{wt} \%$ solution and glycolic acid as a $70 \mathrm{wt} \%$ solution. Table 2-1 shows the amounts of each acid required to make each blend. Additional 80:20 blend was prepared for use in later flowsheet studies. Formic acid alone was also tested as a standard for comparison.

Table 2-1. Glycolic-Formic Acid Blend Preparation

\begin{tabular}{|c|c|c||}
\hline $\begin{array}{c}\text { Mol\% Formic } \\
\text { Acid }\end{array}$ & $\begin{array}{c}\text { 90 wt. \% } \\
\text { Formic Acid } \\
\text { Required (g) }\end{array}$ & $\begin{array}{c}\text { 70 wt.\% Glycolic } \\
\text { Acid Required } \\
\text { (g) }\end{array}$ \\
\hline 5 & 6.07 & 245 \\
\hline 10 & 12.29 & 235 \\
\hline 15 & 19.10 & 230 \\
\hline 20 & 105.87 & 900 \\
\hline 25 & 33.72 & 215 \\
\hline
\end{tabular}

The densities of the acid blends were measured at $25^{\circ} \mathrm{C}$ by using an Anton-Parr instrument at the Aiken County Technology Laboratory (ACTL) Process Science Analytical Laboratory (PSAL). The viscosity of the blends were measured at $25^{\circ} \mathrm{C}$ with a Haake RS600 rheometer using a Newtonian fluid model, that is the measured shear stress is plotted against the applied shear rate resulting in a straight line with a slope that is the apparent viscosity of the material in centipoises (cP). The surface tension of the blends was measured using the capillary rise method where the end of a capillary tube is inserted into the liquid and the height the solution reaches in the capillary is measured. The surface tension of the liquid is calculated by the following equation:

$$
\gamma=\frac{h \rho g r}{2}
$$

where

$\gamma=$ the liquid air surface tension

$\mathrm{h}=$ the height the liquid is lifted

$\rho=$ the density of the fluid

$\mathrm{g}=$ the acceleration due to gravity

$\mathrm{r}=$ the radius of the capillary 
An irradiation test was conducted by adding $\sim 30 \mathrm{~mL}$ of a simulated SRAT product supernate containing glycolic acid from Run GF-13 into a stainless steel vessel with two ports on the threaded lid. ${ }^{11}$ The vessel was irradiated in the Co-60 gamma source at SRNL under a slow flow of argon gas for 24 hours. The dose rate of the Co-60 source was $2.678 \mathrm{E}+05$ Rads/hr providing a total does to the sample of $6.4 \mathrm{Mrad}$. After irradiation, the vessel was opened and the sample visually examined. A small amount of rust colored spots were observed on the bottom of the vessel. The rust colored solids were sampled (using a cotton swab) and sent for analysis. A sample of the post irradiation SRAT product supernate was also obtained for analysis. The remainder of the post irradiation SRAT product supernate was transferred to a flask fitted with a water-cooled condenser and heated to boiling for one hour. After boiling, the SRAT product supernate was examined visually for the presence of solids and sampled for analysis. No visible changes were observed in the solution. A sample of the original SRAT product supernate, the irradiated SRAT product supernate, and the irradiated SRAT product supernate after boiling were sent for analysis by ion chromatography to determine the glycolate ion concentration.

\subsection{Results and Discussion}

\subsection{Physical Property Measurements}

The physical properties of the five prepared acid blends and neat formic acid as a standard were measured as detailed in Section 2.0. These properties as measured are reported in Table 3.1 and Figures 3.1 and 3.2 below. Neat glycolic acid was not measured; however its properties are reported per the vendor specification sheet.

Table 3-1. Physical Properties of Glycolic-Formic Acid Blends

\begin{tabular}{|c|c|c|c||}
\hline Formic Acid (Mole Percent) & Viscosity (cP) & Density (g/mL) & Surface Tension (dyne/cm) \\
\hline $5 \%$ & 7.38 & 1.2581 & 68.85 \\
\hline $10 \%$ & 6.92 & 1.2572 & 58.50 \\
\hline $15 \%$ & 6.91 & 1.2576 & 55.90 \\
\hline $20 \%$ & 6.42 & 1.2567 & 52.55 \\
\hline $25 \%$ & 6.14 & 1.2540 & 55.60 \\
\hline Neat Acids & & & 40.30 \\
\hline 90 wt.\% Formic Acid & 1.5 & 1.1997 & n/a \\
\hline 70 wt. \% Glycolic Acid & 8.6 & 1.27 & \\
\hline
\end{tabular}




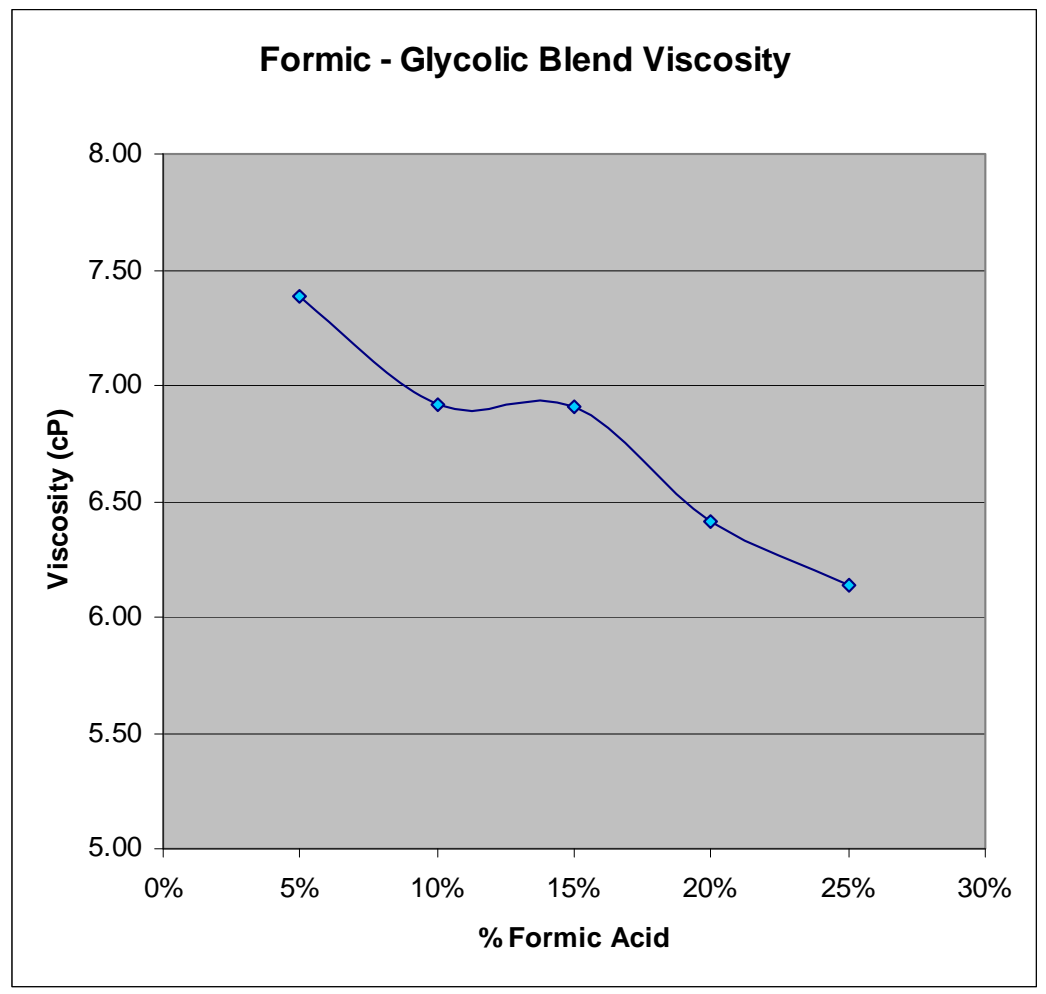

Figure 3-1. Effect of Formic Acid Concentration on Blend Viscosity

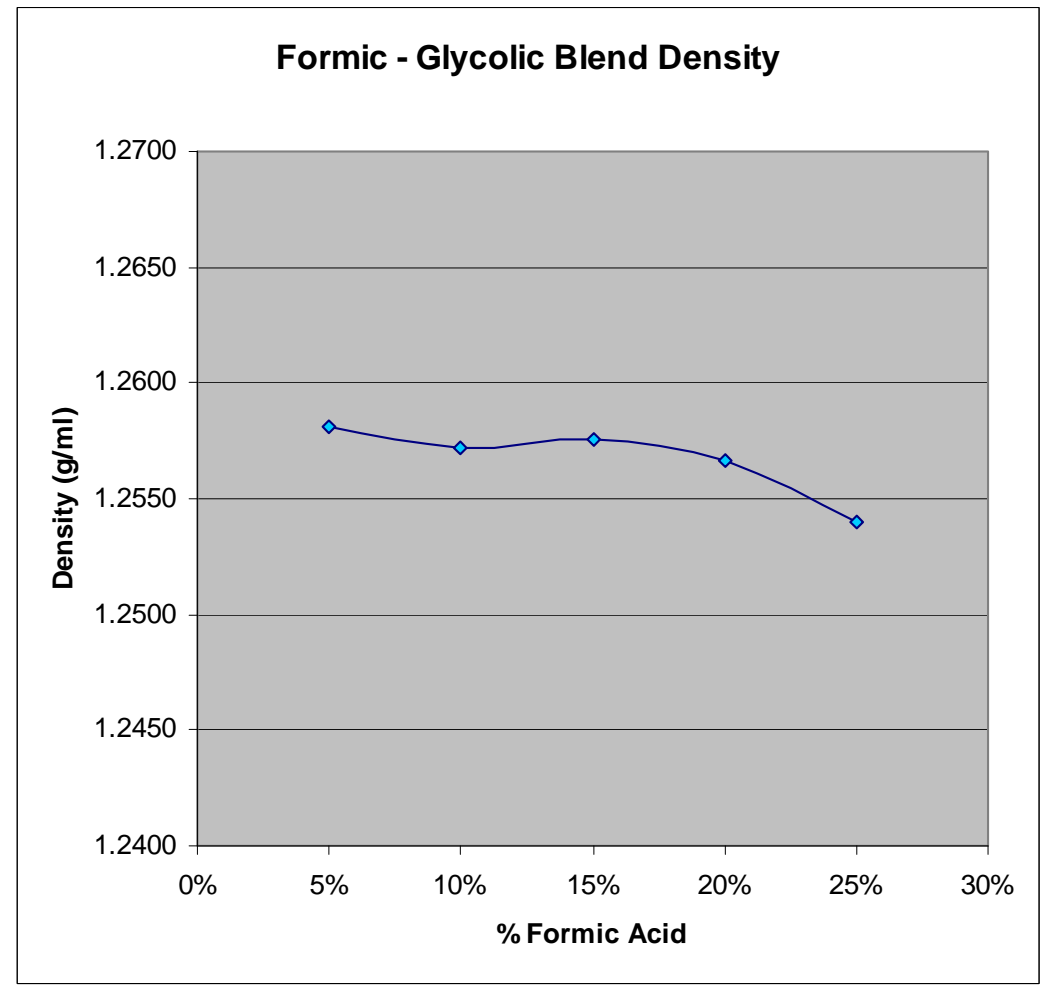

Figure 3-2. Effect of Formic Acid Concentration on Blend Density 
As expected, the inclusion of larger amounts of formic acid leads to decreases in viscosity, density and surface tension. The glycolic-formic blends are more viscous than the $90 \mathrm{wt} . \%$ formic acid that is currently being used but should not present any difficulties in terms of transport. While a more viscous fluid will decrease pump efficiency, viscosity corrections are generally considered negligible for fluids below $40 \mathrm{cP}$.

Communication with DuPont after the issuing of the above report led to the discovery of DuPont data relating density and glycolic acid concentration at $50^{\circ} \mathrm{C}$. This data was developed by titrating the acids, measuring the density and relating acid concentration to molarity. The data was used to calculate the concentration of the pure glycolic acid wt \% and the resulting concentration of the glycolic/formic acid. Based on this data, the as purchased glycolic acid concentration was $71.1 \mathrm{wt} \%$ versus the $70 \mathrm{wt} \%$ assumed throughout the first 20 tests. The data is summarized in Table 3-33 below.

\section{Table 3-2. Glycolic Acid Determination Using Density Measurement}

\begin{tabular}{||c|c||}
\hline $\begin{array}{c}\text { DENSITY, } \\
\text { G/ML @50 }{ }^{\circ} \mathbf{C}\end{array}$ & $\begin{array}{c}\text { WT\% } \\
\text { GLYCOLIC }\end{array}$ \\
\hline 1.196373 & 60.7346 \\
\hline 1.222427 & 67.3276 \\
\hline 1.229959 & 69.0459 \\
\hline 1.238992 & 71.2213 \\
\hline 1.253999 & 75.3670 \\
\hline 1.274718 & 80.2045 \\
\hline 1.288263 & 83.4646 \\
\hline
\end{tabular}

\subsection{Glycolic Acid Impurity Evaluation}

Technical grade glycolic acid can contain sulfates as impurities. Typical analysis is $300-500 \mathrm{ppm}$ but the specification allows for up to $800 \mathrm{ppm}$. The maximum allowable sulfate in the currently used formic acid is $100 \mathrm{ppm}$. An 80:20 molar blend of glycolic and formic acids would therefore contain up to $709 \mathrm{ppm}$ sulfate. The amount of acid added varies based on sludge chemistry and concentration, but a conservatively high acid blend requirement would be about $15 \mathrm{wt} \%$ of the starting sludge mass. For a nominal batch of 1000 grams of SRAT receipt material at $20 \mathrm{wt} \%$ total solids and $13 \mathrm{wt} \%$ calcined solids, this would correspond to 150 grams of glycolic/formic acid blend. This hypothetical SRAT/SME batch would yield about 367 grams of glass. The 150 grams of acid would contribute 0.106 grams of sulfate at the upper limit of $709 \mathrm{ppm}$. The 0.106 grams of sulfate contained in (divided by) 367 grams of glass equates to $0.03 \mathrm{wt} \%$ sulfate in glass contributed by the acid. Note that a lower sulfate content glycolic acid could likely be obtained at some cost if deemed necessary. 


\subsection{Radiation Effects on Glycolic-Formic Acid Blend}

The effect of radiation on the 80:20 molar blend of glycolic-formic acid in the SRAT solution is two-fold. One is the effect of glycolic additions on the radiolytic production of $\mathrm{H}_{2}$ from the SRAT solution during processing in the DWPF. The other is the effect of organic products from the radiolytic decomposition of the glycolic acid on the SRAT solution.

The radiolytic formation of hydrogen was evaluated by comparison of known rate constants for the radiolytic reactions producing $\mathrm{H}_{2}$. Hydrogen atoms from the radiolysis of water (the main component in the SRAT solution) are produced and can react with both formic and glycolic acids or their formate and glycolate ions to produce $\mathrm{H}_{2}$. The hydrogen atoms can also react with nitrate or nitrite ions in the solutions. The reactions with nitrate or nitrite do not produce $\mathrm{H}_{2}$. Consequently there is a competition that affects the rate of production of $\mathrm{H}_{2}$. The rate of radiolytic hydrogen production from formic acid and formate ion in the SRAT solution of Sludge Batch 3 (SB3) has been measured and agrees well with predictions made for the SB3 solution based on its radionuclide composition. ${ }^{3}$ The predictions were based on the known rate constants for the reactions of hydrogen atoms with formate and the nitrate/nitrite ions. This analysis can be extended to a glycolic-formic acid flowsheet.

Rate constants for the reactions of hydrogen atoms with formic and glycolic acids and their corresponding anions have been measured and are published in the radiation chemistry literature. ${ }^{4}$ The rate constant for the reaction with glycolic acid to produce $\mathrm{H}_{2}$ is about 39 times higher than the reaction with formic acid; however, based on the acid dissociation constants for glycolic and formic acids (1.5E-04 and 1.8E-04 respectively), essentially both acids are completely dissociated into glycolate and formate ions in the SRAT solution. It is therefore the reactivity of the ions with hydrogen atoms that is of more concern.

The rate constant for the reaction of glycolate ions with hydrogen atoms is $4.6 \mathrm{E}+07 \mathrm{~L} \mathrm{~mol}^{-1} \mathrm{sec}^{-1}$. This is 4.6 times smaller than the rate constant for the reaction of formate ions $\left(2.1 \mathrm{E}+08 \mathrm{~L} \mathrm{~mol}^{-1}\right.$ $\mathrm{sec}^{-1}$ ). The reactivity of each anion with the hydrogen atoms is the product of its rate constant and its molarity in the SRAT solution. The fractions of hydrogen atoms reacting with each of the four anions can then be calculated from their respective reactivities. This methodology was used in Reference 3 to determine the fraction of radiolytic hydrogen atoms reacting with the formate in the SB3 SRAT solution. In that solution it was calculated that $94 \%$ of the radiolytic hydrogen atoms react with formate to produce $\mathrm{H}_{2}$. The remaining $6 \%$ react with nitrate and nitrite and don't produce $\mathrm{H}_{2}$. Results of the calculations are presented in Table 3-3.

Table 3-3. Fractions of Radiolytic $H$ Atoms Reacting with Formate, Nitrate and Nitrite in SB3 SRAT Solution

\begin{tabular}{|c|c|c|c|c|}
\hline \hline Anion & $\begin{array}{c}\text { Rate Constant } \\
\mathbf{L} / \mathbf{m o l} \cdot \mathbf{s}\end{array}$ & $\begin{array}{c}\text { Concentration, } \\
\mathbf{m o l e} / \mathbf{L}\end{array}$ & $\begin{array}{c}\text { Reactivity, } \\
\mathbf{s}^{\mathbf{- 1}}\end{array}$ & $\begin{array}{c}\text { Fraction } \\
\text { Reacting with } \\
\text { each Anion }\end{array}$ \\
\hline Formate & $2.1 \mathrm{E}+08$ & 0.98 & $2.1 \mathrm{E}+08$ & 0.94 \\
\hline Nitrate & $1.4 \mathrm{E}+06$ & 0.51 & $7.1 \mathrm{E}+05$ & 0.003 \\
\hline Nitrite & $7.1 \mathrm{E}+08$ & 0.08 & $1.4 \mathrm{E}+07$ & 0.06 \\
\hline
\end{tabular}


The effect on hydrogen atom reactivities of substituting glycolic acid for some of the formic acid in the SB3 SRAT to form an 80:20 molar glycolic to formic blend is shown in Table 3-4.

\section{Table 3-4. Reactivities of $\mathrm{H}$ Atoms in a SRAT Solution with 80:20 Molar Blend of Glycolic:Formic Acids}

\begin{tabular}{||c|c|c|c|c|}
\hline Anion & $\begin{array}{c}\text { Rate Constant } \\
\text { L/ mol·s }\end{array}$ & $\begin{array}{c}\text { Concentration, } \\
\mathbf{m o l} / \mathbf{L}\end{array}$ & $\begin{array}{c}\text { Reactivity, } \\
\mathbf{s}^{-1}\end{array}$ & $\begin{array}{c}\text { Fraction } \\
\text { Reacting with } \\
\text { each Anion }\end{array}$ \\
\hline Glycolate & $4.6 \mathrm{E}+07$ & 0.78 & $3.6 \mathrm{E}+07$ & 0.39 \\
\hline Formate & $2.1 \mathrm{E}+08$ & 0.20 & $4.2 \mathrm{E}+07$ & 0.46 \\
\hline Nitrate & $1.4 \mathrm{E}+06$ & 0.51 & $7.1 \mathrm{E}+05$ & 0.008 \\
\hline Nitrite & $7.1 \mathrm{E}+08$ & 0.08 & $1.4 \mathrm{E}+07$ & 0.14 \\
\hline
\end{tabular}

In Table 3-4 it can be seen that in this case $85 \%$ instead of $94 \%$ of the $\mathrm{H}$ atoms would react with the organic anions to produce $\mathrm{H}_{2}$. This would slightly lower the total radiolytic rate of $\mathrm{H}_{2}$ production. Consequently the analysis indicates that substitution of glycolic acid for formic acid would not increase the radiolytic production rate of $\mathrm{H}_{2}$ and cause an adverse effect in the SRAT or SME process. Because the reactivity of glycolate is less than that of formate, considering the effect of nitrite destruction during the SRAT still leads to the conclusion that the net effect is a lower total rate of $\mathrm{H}_{2}$ generation as compared to a formic only flowsheet.

The possible formation of organic compounds from radiolytic decomposition of glycolic acid was also assessed. These compounds are formed primarily by the reactions of hydrogen atoms and hydroxyl radicals $(\mathrm{OH})$ (another reactive intermediate from radiolysis of water) on the glycolate anion. Products from the low dose gamma radiolysis of oxygen saturated aqueous solutions are carbon dioxide (1.9), along with formic (1.6), glyoxylic (2.8) and tartaric (0.04) acids and smaller amounts of oxalic acid and formaldehyde. ${ }^{5}$ The numbers in parentheses are the number of molecules of each product formed per $100 \mathrm{eV}$ of radiation absorbed. The calculation of the 100 $\mathrm{eV}$ yields of the number of carbon atoms in the products indicates that the number of glycolic acid molecules decomposed is 4.5 molecules/100 eV. This yield is very close to that measured for the decomposition of water by gamma radiolysis $\left(4.1\right.$ molecules $\left./ 100 \mathrm{eV}^{6}\right)$ using oxygenated solutions of formic acid. This agreement suggests that reactions for the decomposition of the glycolic acid to form a polymer are not occurring. If a polymer were produced, the $G$ value for the disappearance of glycolic acid would be greater. However, it has been cited that glycolic acid solutions that are depleted of $\mathrm{O}_{2}$ then subjected to large radiation doses (1.5 to 15 Mrad used in study) produced considerable quantities of a non-diffusive polymeric material. ${ }^{8,9}$ This polymer is yellowish white to yellow and soluble in water. The polymer could be converted by heating in a mineral acid to a polymer that was insoluble in water and dilute base. The repeating unit in the polymer was identified as $-\mathrm{C}_{6} \mathrm{O}_{7} \mathrm{H}_{10^{-}}$and had molecular weights greater than $5000 \mathrm{~g} / \mathrm{mol} .{ }^{9}$ The possibility of this occurring in the SRAT solutions has to be considered even though the SRAT solution contains dissolved air. It has been shown that in the radiolysis of water containing organic solutes, oxygen can be depleted at large radiation doses by reactions with the organic radicals with the $\mathrm{O}_{2} \cdot{ }^{10}$ In the SRAT, this $\mathrm{O}_{2}$ can only be replenished by the diffusion of atmospheric air into the solution. Consequently, in the DWPF the radioactive SRAT solutions may become oxygen depleted and the polymer may form at large radiation doses. Considering a 
constant air purge is maintained in the SRAT and the solution is continuously mixed, oxygen depletion seems unlikely, however, if this polymer is formed in the SRAT solution, the rheology of the solution may be affected and pumping of the solution may be hindered.

\subsection{Radiation Effects on Simulated SRAT Product Supernate}

An irradiation test was completed to determine whether a SRAT product supernate containing glycolic acid will form polymers. SRAT Supernate from Run GF-13 ${ }^{11}$, a simulated SRAT supernatant, was irradiated in the Co-60 gamma source at SRNL under a slow flow of argon gas to a dose of 6.4 Mrad (approximately the dose received by the radioactive SRAT solution after 5 weeks based on a SB-6 composition). No visible changes were observed in the SRAT product supernate after irradiation (Figure 3-3). However, a small amount of dark colored solids was observed on the bottom of the vessel. The solids on the bottom of the vessel appeared to be spots of rust and were sampled using a cotton swab. The elemental analysis of the solids found Fe, Mn, and $\mathrm{Na}$ to be the major components consistent with either precipitation of these elements from solution or resulting from steel corrosion products. The solids also contained minor amounts of $\mathrm{Al}, \mathrm{Ca}, \mathrm{Cr}$ and Ni. The irradiated SRAT product supernate was heated to reflux for 1 hour, and again, no visible changes occurred to the solution. Analysis of samples of the original SRAT product supernate, the irradiated SRAT product supernate, and the irradiated SRAT product supernate after boiling for 1 hour showed no significant change in the glycolate concentration (Table 3-5). No evidence for the formation of organic polymers was found.

Table 3-5. Anion Analysis of the SRAT Product Supernate Samples

\begin{tabular}{|c|c|c|c|}
\hline Anion * & $\begin{array}{c}\text { Orig. SRAT } \\
\text { Product } \\
\text { Supernate } \\
\text { (mg/L) }\end{array}$ & $\begin{array}{c}\text { Irradiated } \\
\text { SRAT Product } \\
\text { Supernate } \\
\text { (mg/L) }\end{array}$ & $\begin{array}{c}\text { Irradiated and } \\
\text { Boiled SRAT } \\
\text { Product Supernate } \\
\text { (mg/L) }\end{array}$ \\
\hline Glycolate & $3.40 \mathrm{E}+04$ & $4.02 \mathrm{E}+04$ & $3.77 \mathrm{E}+04$ \\
\hline Formate & $1.33 \mathrm{E}+03$ & $1.05 \mathrm{E}+03$ & $<1.0 \mathrm{E}+03$ \\
\hline Nitrate & $8.86 \mathrm{E}+04$ & $1.14 \mathrm{E}+05$ & $1.07 \mathrm{E}+05$ \\
\hline Nitrite & $<9.9 \mathrm{E}+02$ & $<9.8 \mathrm{E}+02$ & $<1.0 \mathrm{E}+03$ \\
\hline Oxalate & $4.48 \mathrm{E}+03$ & $3.88 \mathrm{E}+03$ & $4.20 \mathrm{E}+03$ \\
\hline Sulfate & $5.22 \mathrm{E}+03$ & $7.05 \mathrm{E}+03$ & $6.83 \mathrm{E}+03$ \\
\hline Phosphate & $<9.9 \mathrm{E}+02$ & $<9.8 \mathrm{E}+02$ & $<1.0 \mathrm{E}+03$ \\
\hline Chloride & $1.54 \mathrm{E}+03$ & $2.17 \mathrm{E}+03$ & $2.06 \mathrm{E}+03$ \\
\hline Fluoride & $<9.9 \mathrm{E}+02$ & $<9.8 \mathrm{E}+02$ & $<1.0 \mathrm{E}+03$ \\
\hline
\end{tabular}

* Anion analysis by ion chromatography. All results are the average of duplicate measurements. 


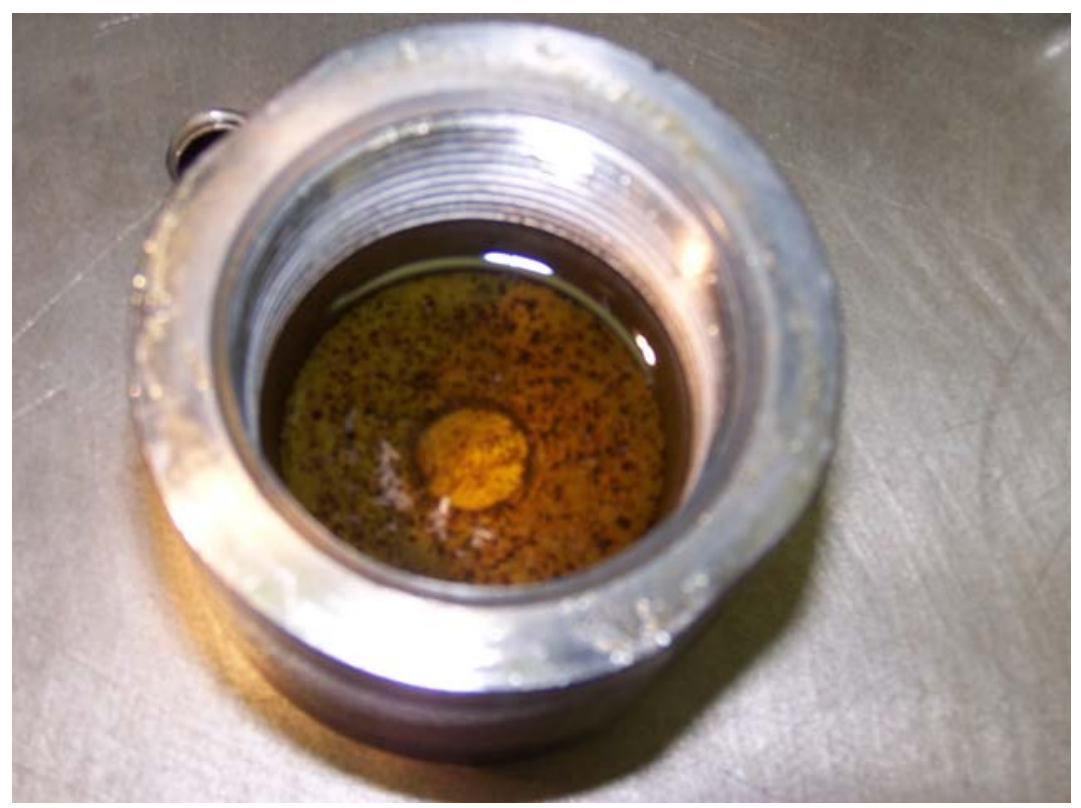

Figure 3-3. GF-13 Post SRAT Supernate after Irradiation

\subsection{Conclusions}

The physical properties of glycolic acid were studied as they relate to DWPF processing. In summary, there are no immediate concerns from a physical property standpoint in implementing a glycolic acid flowsheet. From this study, the following conclusions can be drawn:

- Adding more glycolic acid will increase the density, viscosity, and surface tension of the glycolic/formic acid blend. This is not expected to present any difficulties in pumping of the material.

- Changing to a glycolic acid flowsheet may increase the sulfate level in glass by up to $0.03 \mathrm{wt} \%$.

- Introducing glycolic acid to high radiation doses may cause some polymerization of the acid in an oxygen depleted atmosphere. The rheology of the SRAT and SME products may thus increase by some amount, but the effect is expected to be minor. However, an irradiation test with a simulated SRAT product supernate containing glycolic acid in an oxygen depleted atmosphere did not find evidence of polymerization. 
SRNL-STI-2010-00314

Revision 1

\subsection{References}

${ }^{1}$ Holtzscheiter, E.W., Perform Glycolic-Formic Acid flowsheet Development, Definition, and Demonstration, HLW-DWPF-TTR-2010-0003 Rev. 0, December 2009.

${ }^{2}$ Pickenheim, B.R. and D.R. Best., Task Technical and Quality Assurance Plan for GlycolicFormic Acid Flowsheet Development, Definition, and Demonstration Tasks 1-3, SRNL-RP-201000105 Rev. 0, February 2010.

${ }^{3}$ Bibler, N.E, J.M. Pareizs, T.L. Fellinger, and C.J. Bannochie, Measurement and Prediction of Radiolytic Hydrogen Production in Defense Waste Processing Slurries at Savannah River Site, Waste Management Conference 2007, February 2007.

${ }^{4}$ Buxton, G.V., C.L. Greenstock, W.P. Helman, and A.B. Ross, Critical Review of Rate Constants for Reactions of Hydrated Electrons, Hydrogen Atoms and Hydroxyl Radicals (OH/O-) in Aqueous Solution, J. of Phys. and Chem. Ref. Data, 1988.

${ }^{5}$ Grant, P. M. and R. B. Ward, Effects of $\gamma$-Radiation. Part III. Quantitative Studies of the Products from Glycolic Acid, J. Chem. Soc. p. 2659, (1959).

${ }^{6}$ Draganic', I. G., M. T., Nenadovic', and Z. D. Draganic', Radiolysis of $\mathrm{HCOOH}+\mathrm{O}_{2}$ at $\mathrm{pH} 1.3$ 13 and the Yields of Primary Products in $\gamma$-Radiolysis of Water, J. Phys. Chem. 73, 2564 (1969).

${ }^{7}$ Grant, P. M. and R. B. Ward, Effects of $\gamma$-Radiation. Part II. Characterization of the Products from Glycolic Acid, J. Chem. Soc, p. 2654, (1959).

${ }^{8}$ Barker, S. A., P. M. Grant, M. Staycey, and R. B. Ward, Effects of $\gamma$-Radiation. Part I. Polymer Formation from Sugars, Hydroxy acids and aAmino-Acids, J. Chem. Soc. p. 2648, (1959).

${ }^{9}$ Stacey, M., S. A. Barker, R. B. Ward, P. M. Grant, I. R. L. Lloyd, Polyamino and Polyhydrocarboxylic Acids, Great Britain Patent No. 901037, Intellectual Property Office, Cardiff Road, Newport South Wales, NP 10 800, United Kingdom, July 11, 1962.

${ }^{10}$ Spinks, J. W. T. and R. J. Woods, “An Introduction to Radiation Chemistry,” 2nd Ed., p 375, John Wiley \& Sons, Inc. 1964.

${ }^{11}$ D.P. Lambert, B.R. Pickenheim, M.E. Stone, J.D. Newell, D.R. Best, Glycolic - Formic Acid Flowsheet Final Report for Downselection Decision, SRNL-STI-2010-00529 Rev. 1, March 2011. 


\section{Distribution:}
A. B. Barnes, 999-W
D. A. Crowley, 773-43A
S. D. Fink, 773-A
B. J. Giddings, 786-5A
C. C. Herman, 999-W
S. L. Marra, 773-A
A. M. Murray, 773-A
F. M. Pennebaker, 773-42A
W. R. Wilmarth, 773-A
C. J. Bannochie, 773-42A
J. M. Gillam, 766-H
B. A. Hamm, 766-H
J. F. Iaukea, 704-30S
D. D. Larsen, 766-H
D. J. McCabe, 773-42A
R. T. McNew, 704-27S
J. E. Occhipinti, 704-S
D. K. Peeler, 999-W
J. W. Ray, 704-S
H. B. Shah, 766-H
D. C. Sherburne, 704-S
M. E. Stone, 999-W

J. M. Bricker, 704-27S

T. L. Fellinger, 704-26S

E. W. Holtzscheiter, 704-15S

H. M. Pittman, 704-27S

K. R. Shah, 704-S

A. I. Fernandez, 999-W

J. D. Newell, 999-W

D. C. Koopman, 999-W

J. M. Pareizs, 773-A

S. H. Reboul, 773-A

W. T. Riley, 999-W

D. R. Best, 999-W

R. E. Eibling, 999-W

J. P. Vaughan, 773-41A 